Oral Health

\title{
ORAL HYGIENE AND FLUORIDE INFLUENCE ON DENTAL HEALTH IN EARLY CHILDHOOD
}

\author{
Olga Kokoceva-Ivanovska ${ }^{1}$ \\ Department of Children Preventive Dental Medicine, Faculty of Dental Medicine, Ss. Cyril and Methodius \\ University in Skopje, Republic of North Macedonia
}

\begin{abstract}
Citation: Kokoceva Ivanovska O. Oral hygiene and fluoride influence on dental health in early childhood. Arch Pub Health 2021; 13 (1).

doi.org/10.3889/aph.2021.5997

Key words: $\mathrm{OHI}$ index, initial lesion, superficial lesion, fluoride treatment

*Correspondence: Olga Kokoceva Ivanovska. Department of Children Preventive Dental Medicine Faculty of Dental Medicine, Ss. Cyril and Methodius University in Skopje, Republic of North Macedonia. E-mail: olga.kokoceva@gmail.com

Received: 8-Jan-2021; Revised: 5-Apr-2021; Accepted: 13-Apr-2021; Published: 15-Apr-2021 Copyright: ${ }^{2021}$. LOlga Kokoceva Ivanovska This is an open-access article distributed under the terms of the Creative Commons Attribution License, which permits unrestricted use, distribution, and reproduction in any medium, provided the original author(s) and source are credited.

Competing Interests: The author have declared that no competing interests
\end{abstract}

\section{Abstract}

Early childhood caries occurs immediately after the eruption of deciduous teeth. During this period, children are too young to be able to properly implement oral hygiene. Consequently, it is at a negligible level, with plenty of soft plaque on the deciduous tooth surfaces. The objective of this investigation was to determine the correlation between oral hygiene (shown with the $\mathrm{OHI}$ index) and the initial stages of early childhood caries: initial lesion (white spot) and superficial form, before and after local fluoride treatment. Material and methods: For determining the $\mathrm{OHI}$ index among our examinees we used the method of Green-Vermillion. It was determined in 117 examinees twice, during the first visit and immediately before physiological replacement of deciduous teeth. Patients were two to three years of age, diagnosed with initial stages of early childhood caries and fluoride preparate (amino fluoride solution) was applied once a week, for 6 months. Results: In 30 subjects treated with local fluoride treatment from both basic groups (with initial and superficial lesions), just before the physiological change of the teeth, we received a statistically significant improvement in the $\mathrm{OHI}$ index ( $=0.000038 ; \mathrm{p}=0.00006)$ at the end from the examination. Conclusion: From the conducted analysis of the obtained results, we can conclude that the level of oral hygiene is correlated with the progression of changes in the enamel. Oral hygiene and fluoride treatment significantly reduce soft tissue levels and improve the $\mathrm{OHI}$ index.

\section{Орално здравје}

\section{ВЛИЈАНИЕТО НА ОРАЛНАТА ХИГИЕНА И ФЛУОРИДИТЕ НА ДЕНТАЛНОТО ЗДРАВЈЕ ВО РАНАТА ДЕТСКА ВОЗРАСТ}

\author{
Олга Кокочева-Ивановска ${ }^{1}$

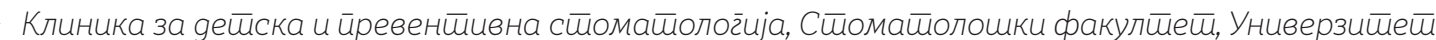 \\ „Св. Кирил и Мейоguj"- Скойје, Северна Макеgонија
}

\begin{abstract}
Цитирање: Кокочева-Ивановска О. Влијание то на оралната хигиена и флуоридите на денталното здравје во раната детска возраст. Арх Здравје 2021:13(1)

doi.org/10.3889/aph.2021.5997
\end{abstract}

Клучни зборови: ОНІ индекс, иницијална лезија, суперфицијална лезија, флуориден третман

*Кореспонденција: Олга Кокочева-Ивановска, Клиника за детска и превентивна стоматологија, Стоматолошки факултет, Универзите Св. Кирил и Методиі“, Скопје, Северна Македонија. E-mail: olga.kokoceva@gmail.com

Примено: 8-ан-2021; Ревидирано: 5-апр-2021; Прифатено: 13-апр-2021; 0бјавено: 15-апр-2021

Печатарски права: ${ }^{\circ 2021 ~ О л г а ~ К о к о ч е в а-И в а-~}$ новска. Оваа статија е со отворен пристап дистрибуирана под үсповите на нелонализиран рибуирана под услвике на нелокализиран

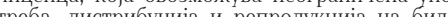
тес, дистрибуци кој медиум, доколку се цитираат оригиналниот(ите) автор(и) и изворот.

Конкурентски интереси: Авторот изјавува дека нема конкурентски интереси.

\section{Извадок}

Кариесот на раното детство се јавува веднаш по ерупцијата на млечните заби. Во овој период, детето е сѐуште многу мало за да може правилно да ја спроведува својата орална хигиена. Од тие причини, оралната хигиена е на незначително ниво, со изобилство на меки наслаги на забните површини од млечните заби. Целта на ова истражување беше да ја одредиме корелацијата помеѓуоралната хигиена (прикажана со ОНІ индекс) и почетните стадиуми на кариесот на раното детство: иницијална лезија и суперфицијална форма, пред и после спроведен локален флуориден третман. Материјал и методи: Одредувањето на ОНІ индексот кај нашите испитаници го вршевме според методата на Green-Vermillion во два наврата: при првата посета, при дијагностицирање на заболувањето и непосредно пред физиолошката смена на забите, на крај од испитувањето. Во клиничкото иследување, беа вклучени 117 испитаници, на возраст од две до три години, со комплетно формирано млечно забало, кај кои дијагностициравме почетни стадиуми на циркуларен кариес: иницијална лезија или бела дамка (macula alba) и суперфицијална лезија. За локален флуориден третман аплициравме флуориден препарат (аминофлуориден раствор), еднаш неделно, во период од 6 месеци. Резултати: Кај 30 испитаницикои беа третирани со локален флуориден третман и од двете основни групи (соиницијални и суперфицијални лезии), непосредно пред физиолошката смена на забите,добивме статистички позначајно подобрувањето на ОНІ индексот ( $p=0,000038 ; \mathrm{p}=0,00006)$ на крајот од испитувањето. Заклучок: Од спроведените анализи на добиените резултати, можеме да констатираме дека нивото на оралната хигиена е во корелација со прогресијата на промените во емајлот. Оралната хигиена и флуоридниот третман значително влијаат врз намалување на нивото на меките наслаги и подобрување на ОНІ-индексот. 


\section{Вовед}

Во периодот на раното детство $0^{1,2,3}$, детето е сѐ уште многу мало за да може правилно да ја спроведува својата орална хигиена. Од тие причини, оралната хигиена ${ }^{4,5}$ е на незначително ниво, со изобилство на меки наслаги на забните површинина млечните заби. Овие меки наслаги понатаму служат како резервоар на храна (богата со шеќери) $)^{3,6,7}$ за бактериите кои ги разградуваат шеќерите со продукција на киселини кои ја атакуваат површината на емајлот ${ }^{2,6}$. Киселата средина во оралниот медиум доведува до пад на $\mathrm{pH}$ на плунката под критичната вредност $(5,5)^{1,4,7}$ што резултира со почетна деминерализација ${ }^{5,6,7}$ на емајлот и појава на првите промени во гингивалната третина од вестибуларните површини на млечните заби ${ }^{8,9}$, зафаќајќи ги најпрво горните млечни инцизиви, со промени во вид на бели дамки (whitespotlesions) т.н.иницијална лезија ${ }^{7,10}$. Кариесот на раното детство има акутен, прогресивен тек, се шири во круг по што го среќаваме и како циркуларен кариес (circulum-круг) ${ }^{1}$. Според Weerkamp и Weerheijm11 минува низ четири фази, од кои ние превентивно можеме да делуваме во почетните две фази: иницијална лезија или бела дамка, која е без симптоми и е реверзибилна ${ }^{12}$; и суперфицијална лезија кога се јавува осетливост на студено. При ерупцијата на забите кај децата има акумулација на плак во подолг временски период ${ }^{8}$ бидејќи е оневозможно да се одржува комплетна орална хигиена кај новороденчето, а исто така и површината на емајлот е сѐ уште порозна поради постеруптивната матурација која е штотуку започната ${ }^{10}$. По вклучувањето на забите во функција ${ }^{8}$ доаѓ до делумно отклонување на дел од плакот од површината на забите и ако дојде до вопоставување на орална хигиена и отстранување на плакот, но во присуство на флуориди, ќе дојде до реминерализација на оштетените кристали во иницијалната лезија. Во иницијалната лезија кариесот ја нема целосно пробиено глеѓно-дентинската граница и глеѓта е навидум интактна. Но, под површината на инцијалната кариозна лезија или белата дамка постои дел со изгубени минерали токму под таа интактана површина од глеѓта. Тој дел со помалку минерали е способен за реверзибилен процес на реминерилазација. Реминерализацијата е процес на депозиција на минерални елементи, пред сѐ калциум и фосфати ${ }^{13}$, во иницијалната кариозна лезија, кои при процесот на деминерализација преминуваат од површнските слоеви на глеѓта во плакот и плунката. Со реминерализацијата се зголемуваат хидроксилните апатити ${ }^{14,15}$ и доколку е присутен во медиумот флуор, ќе се создадат и флуорапатити коишто се поотпорни на кисела средина. Во исто време, го инхибира процесот на деминерализација ${ }^{12}$ делувајќи инхибиторно на метаболичките активности на кариогените бактерии, делувајќи бактерицидно и бактериостатски, со ензимска инхибиција во плакот при гликолизата. Реминерализацијата ${ }^{12,13}$ е третман за активирање на иницијална некавитирана кариозна лезија, овозможувајќи реверзибилност на процесот или најмалку стопирање на прогресијата кон кавитирање. Колку ќе биде ус- 
пешна реминерализацијата зависи од тоа кои фактори преовладуваат, протективните или патогените.

Цел на трудот беше да ја одредиме корелацијата помеѓу оралната хигиена (прикажана со ОНІ-индекс) и почетните стадиуми на кариесот на раното детство: иницијална лезија и суперфицијална форма, пред и после спроведен локален флуориден третман.

\section{Материјал и методи}

OHI индексот (Oral Hygiene Index) ја изразува оралната хигиена кај пациентот, односно ја изразува застапеноста на наслагите на површината од забите. Најчесто употребуван индекс за одредување на меките наслаги е Green-Vermillionовиот индекс. ${ }^{16}$

Начин на бодирање на присуството на меки наслаги според методата на Green-Vermillion:

\begin{tabular}{|c|l|}
\hline Бодови & Присуство на меки наслаги \\
\hline 0 & нема меки наслаги \\
\hline 1 & меките наслаги покриваат до $1 / 3$ од површината на забот \\
\hline 2 & меките наслаги покриваат од $1 / 3$ до $2 / 3$ од површината на забот \\
\hline 3 & меките наслаги покриваат над $2 / 3$ од површината на забот \\
\hline
\end{tabular}

Оваа метода ни овозможува на едноставен начин да се истражува и нумерички одреди присуството на меките наслаги. Се класифицира во четири класи означени од 0 до 3.

За спроведување на ова клиничко испитување, со стандарден клинички преглед на Клиниката за детска и превентивна клиника, од вкупниот број на прегледани испитаници вклучивме вкупно 117 испитаници од различен пол, на возраст од две до три години, од кои формиравме две основни целни групи испитаници: 61 испитаник со почетна, иницијална лезија (бела дамка) и 57 испитаници со суперфицијална лезија . Понатаму од овие две основни групи, одвоивме по ист број испитаници, 30 испитаници, кои ги третиравме со локален флуориден третман. Употребувавме органски флуориден препарат, аминофлуориден раствор12 еднаш неделно во период од 6 месеци. $1 \mathrm{ml}$ раствор содржи $10 \mathrm{mg}$ флуор (1\%) во облик на олафлур $(0,925 \%)$ и дектафлур (0,075\%), а како помошни состојки се сахарин, арома 46 и дестилирана вода. Комбинацијата на два аминофлуорида (олафлур и дектафлур) кои се површински активни добро се прилепуваат на глеѓта и овозможуват долготраен контакт со него17. Одредувањето на ОНІ индексот го вршевме кај сите испитаници нетретирани и третирани со локален флуориден третман со Green-Vermillion-овиот индекс за присуството на меки наслаги16, во два наврата: при првата посета на Клиниката за детска и превентивна стоматологија при дијагностицирањето на иницијалната и суперфицијална 
лезија (во 2010 год.) и непосредно пред физиолошката смена на горните централни инцизиви на испитаниците, т.е на крај од испитувањето (во 2014-15год.). Во тек на испитувањето, најпрво спроведувавме едукација кај мајките (родителите), за подобрување на оралната хигиена кај децата. Ги едуциравме со совети за правилно одржување на хигиено-диететскиот режим кај нивните деца т.е. им ја демонстриравме правилната техника на четкање на заби, како да им помагаат во почетокот на своите дечиња правилно да научат да ги четкаат забите и во домашни услови. Исто така им дававме совети да ги насочуваат децата на правилен начин на исхрана и консумирање здрава храна ${ }^{18}$. Потоа им напоменавме и дека четкичката за заби треба да е мека и да се менува на секои 6 месеци, во спротивно влакната на четката ќе се деформираат и нема ефикасно да ги отстрануваат меките наслаги или ќе ги внесувааат во меѓузабните простори. На мајките на испитаниците кои сѐ уште користеа шише во исхраната ${ }^{19}$ исполнето со засладени содржини им дававме инструкции за одвикнување на детето од шише, во најкраток временски период.

Кај сите испитаници вршевме редовни контроли еднаш месечно, при што спроведувавме: професионално отстранувње на присутните заостанати меки наслаги, со посебна процедура: со колењак и ротирачка четка нанесуваме професионална паста за отстранување на меки наслаги на забните површини и во присуство на сисалка и голема претпазливост детето да не го проголта вишо- кот од пастата, ги поминувавме сите површини на млечнит заби. На крај, забите се плакнеа со пустер со вода, за да се отстранат остатоци од пастата, доколку сѐ уште имаше. Кај 30-те испитаници од двете групи со иницијална и суперфицијална лезија, кај кои спроведувавме локален флуориден третман со аминофлуориден раствор, по оваа процедура забите се сушеа со пустер и се нанесуваше со тупферче многу внимателно флуоридниот препарат. Се премачкувааа сите забни површини и оставаа да се исушат 1-2 мин. Потоа на родителите и децата им напоменувавме децата да не јадат ниту пијат водаполовина час, додека дејството на средството е најголемо.

Родителите на децата пополнуваа прашалник за навиките на одржување орална хигиена и дневната фреквенција на четкање на заби кај децата.

\section{Резултати}

На графикон број 1 се прикажани обработените податоци од анкетата спроведена кај испитаниците во оваа студија, за навиките за одржување орална хигиена и дневна фреквенција на четкање заби. Добивме резултати дека најголем процент од испитаниците (56\%), не ги миеле забите. Од испитаниците, 32\% ги миеле забите еднаш дневно, а само12\% двапати дневно. Оралната хигиена беше на многу оскудно ниво. Нашите резултати беа во границите на резултатите од испитувањата на други автори $1,3,5,8,11$ 


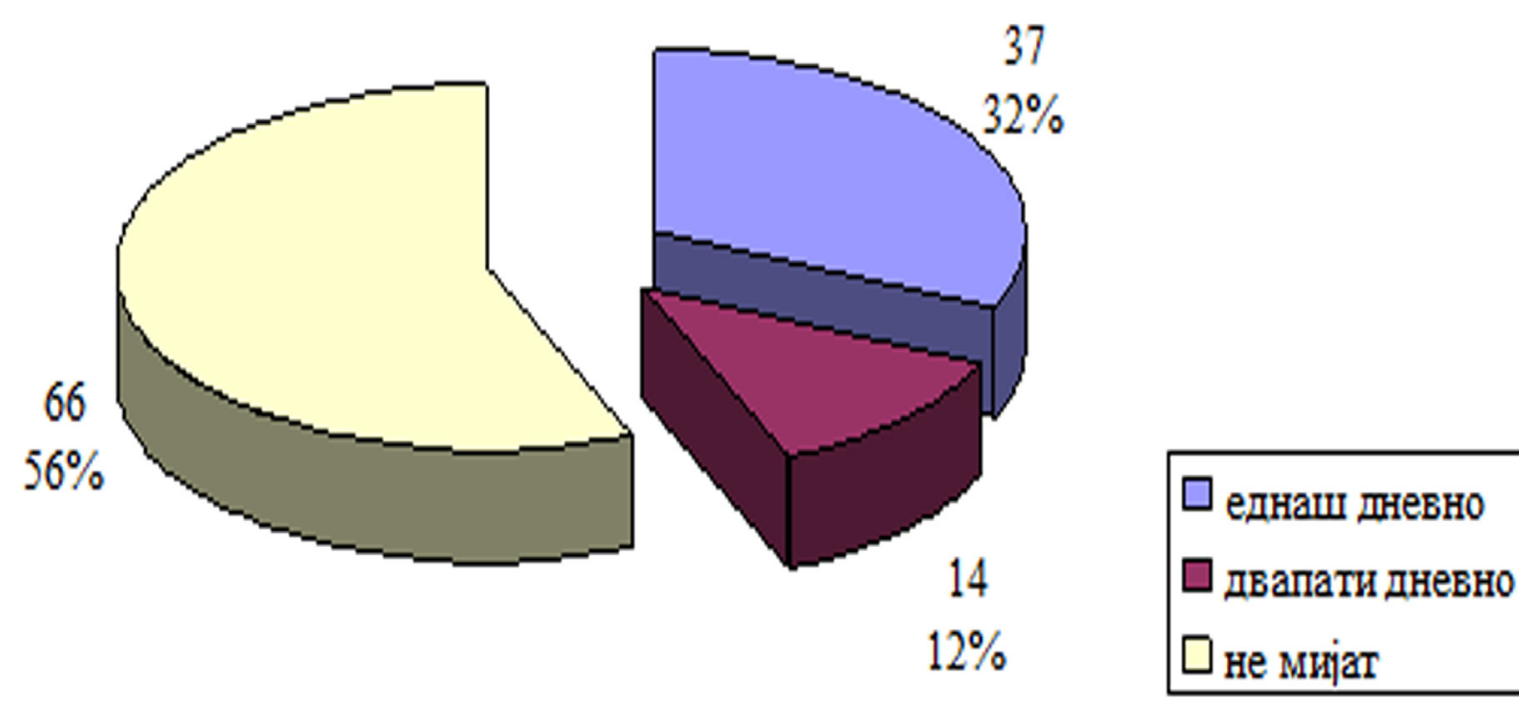

Графикон 1: Навики за одржување орална хигиена и дневна фреквенција на четкање заби кај децата

Во табела број 1, се дадени вредностите на ОНІиндексот за оралната хигиена кај испитаниците со иницијална лезија, одредени при првата посета (на почетокот од испитувањето) и непосредно пред физиолошката смена на забите (на крајот од испитувањето), кај двете групи, нетретирани и третирани испитаници со локален флуориден третман (p-p аминофлуорид). Вкупно беа 61 испитаник со иницијална, почетни лезија, од кои 31 нетретирани, а 30 третирани со локален флуориден третман. Кај нетретираните 31 испитаник, при првиот преглед, ОНІиндекс со вредност над 2 имаа 21 (67,74\%.) испитаници. Кај втората група од 30 испитаници, кои подоцна беа подложени на топикален флуориден третман, при првата посета 17 $(56,67 \%)$ имаа индекс на меки на- слаги над 2. Ова укажува на фактот дека и двете групи испитаници не одржувале орална хигиена. Помеѓу третираните и нетретираните испитаници со иницијална лезија постоеше статистички сигнификантна разлика во однос на подобрувањето на ОНІиндексот (пред физиолошката смена) т.е. на крајот од испитувањето (MannWhitney U Test: $Z=2,036 ; \quad p=$ 0,04165). Одредените ОНІиндекси и кај двете групи укажуваа на значително подобрување на индексот, односно најголем број испитаници ѝ припаѓаa на групата со најнизок т.е. (најдобар) ОНІиндекс со вредност од 0 до 1(веќе немаше меки наслаѓи на забните површини или само до $1 / 3$ од површината на забот). 
Табела 1: Вредности на ОНІиндексот кај нетретираните и третираните испитаници со иницијална лезија (macula alba)

\begin{tabular}{|c|c|c|c|c|c|c|c|}
\hline \multicolumn{8}{|c|}{ Испитаници со иницијална лезија (macula alba) (N = 61) } \\
\hline \multicolumn{4}{|c|}{$\begin{array}{c}\text { Нетретирани } \\
31\end{array}$} & \multicolumn{4}{|c|}{$\begin{array}{c}\text { Третирани } \\
30\end{array}$} \\
\hline \multirow{2}{*}{$\begin{array}{c}\text { Период на } \\
\text { одредување }\end{array}$} & \multicolumn{3}{|c|}{ ОНІиндекс } & \multirow{2}{*}{$\begin{array}{l}\text { Период на } \\
\text { одредување }\end{array}$} & \multicolumn{3}{|c|}{ ОНІиндекс } \\
\hline & $0-1$ & $1,1-2$ & $2,1-3$ & & $0-1$ & $1,1-2$ & $2,1-3$ \\
\hline \multirow{2}{*}{$\begin{array}{l}\text { При прва } \\
\text { посета }\end{array}$} & 3 & 7 & 21 & \multirow{2}{*}{$\begin{array}{c}\text { При прва } \\
\text { посета }\end{array}$} & 2 & 11 & 17 \\
\hline & $9,68 \%$ & $22,58 \%$ & $67,74 \%$ & & $6,67 \%$ & $36,67 \%$ & $56,67 \%$ \\
\hline \multirow{2}{*}{$\begin{array}{c}\text { Пред } \\
\text { физиолошка } \\
\text { смена }\end{array}$} & 15 & 11 & 5 & \multirow{2}{*}{$\begin{array}{c}\text { Пред } \\
\text { физиолошка } \\
\text { смена }\end{array}$} & 21 & 9 & 0 \\
\hline & $48,39 \%$ & $35,48 \%$ & $16,13 \%$ & & $70,00 \%$ & $30,00 \%$ & $0,00 \%$ \\
\hline
\end{tabular}

При споредување на измерените вредности на индексот на меки наслаги, кај третираната група на испитаници со иницијална лезија, со локален флуориден третман, подобрувањето на вредноста на индексот беше статистички значително повисока во однос на нетретираната група (Wilcoxon Matched Pairs Test: $\mathrm{Z}=4,622 ; \mathrm{p}=$ $0,000038)$. Ова покажа дека флуоридите, освен врз процесот на реминерализација кај иницијалните лезии, значително влијаеше и врз намалување на нивото на меките наслаги. На крајот на испитувањето, најголем процент од двете групи испитаници беа со индекс од 0 до 1 , но евидентно повисок беше процентот на третираната група (70\%) во однос на нетретираната $(48,39 \%)$ со иницијални лезии.

Во табела број 2, прикажани се по истиот редослед, вредностите на ОНІиндексот кај испитаниците со суперфицијална лезија, односно површински кариес во глеѓта на млечните заби со кариес на рано детство. Вкупно беа 56 испитаници. Од нив 26 беа нетретирани, а 30 третирни со локален флуориден третман, на истиот начин како и испитаиците со иницијална лезија. Кај двете групи испитаници со суперфицијална лезија при првата посета, најзастапен беше процентот на испитаници со висок ОНІ индекс (2,1-3), кој изнесуваше околу 70\% за двете групи, што исто значи дека овие испитаници имаа уште пооскудна орална хигиена од испитаниците со иницијална лезија. Кај испитаниците со суперфицијална лезија со локален флуориден третман, постоеше голема статистички сигнификантна значајна разлика на ОНІиндексот на крај од испитувањето (Wilcoxon Matched Pairs Test: $Z=4,540 ; p=0,00006)$. И кај оваа група испитаници се покажа истиот ефект на флуоридите, стопирање на проградирањето на површинскиот кариес (суперфицијална лезија) во подлабок кариес и редукција на меките наслаги од забните површини. 
Табела 2: Вредности на ОНІиндексот кај нетретираните и третираните испитаници со суперфицијална форма

\begin{tabular}{|c|c|c|c|c|c|c|c|}
\hline \multicolumn{8}{|c|}{ Испитаници со суперфицијална форма ( $\mathrm{N}$ = 56) } \\
\hline \multicolumn{4}{|c|}{$\begin{array}{l}\text { Нетретирани } \\
26\end{array}$} & \multicolumn{4}{|c|}{$\begin{array}{c}\text { Третирани } \\
30\end{array}$} \\
\hline \multirow{2}{*}{$\begin{array}{c}\text { Период на } \\
\text { одредување }\end{array}$} & \multicolumn{3}{|c|}{ ОНІиндекс } & \multirow{2}{*}{$\begin{array}{c}\text { Период на } \\
\text { одредување }\end{array}$} & \multicolumn{3}{|c|}{ ОНІиндекс } \\
\hline & $0-1$ & $1,1-2$ & $2,1-3$ & & $0-1$ & $1,1-2$ & $2,1-3$ \\
\hline \multirow{2}{*}{$\begin{array}{l}\text { При прва } \\
\text { посета }\end{array}$} & 0 & 7 & 19 & \multirow{2}{*}{$\begin{array}{c}\text { При прва } \\
\text { посета }\end{array}$} & 1 & 8 & 21 \\
\hline & $0,00 \%$ & $26,92 \%$ & $73,08 \%$ & & $3,33 \%$ & $26,67 \%$ & $70,00 \%$ \\
\hline \multirow{2}{*}{$\begin{array}{c}\text { Пред } \\
\text { физиолошка } \\
\text { смена }\end{array}$} & 12 & 10 & 4 & \multirow{2}{*}{$\begin{array}{c}\text { Пред } \\
\text { физиолошка } \\
\text { смена }\end{array}$} & 18 & 10 & 2 \\
\hline & $46,15 \%$ & $38,46 \%$ & $15,38 \%$ & & $60,00 \%$ & $33,33 \%$ & $6,67 \%$ \\
\hline
\end{tabular}

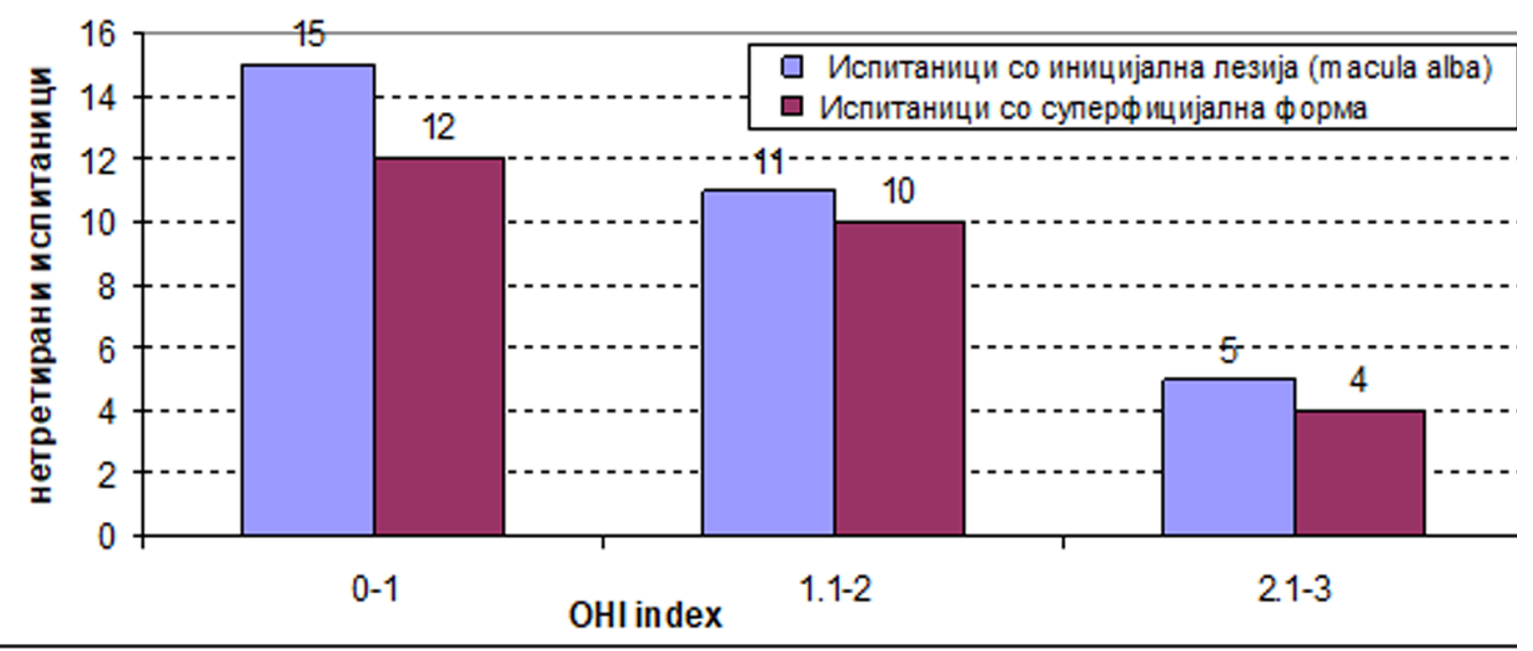

Графикон 2: Споредба на нетретираните испитаници со иницијална лезија и со суперфицијална форма на кариес

На графикон 6р.2 дадена е споредба на нетретираните испитаници со иницијална лезија и суперфицијалналезијана крајотод испитувањето со статистичка разлика во однос на ОНІиндексот (Mann-Whitney U Test: $\mathrm{Z}=2,366$; $\mathrm{p}$ $=0,01796)$, во прилог на испитаниците со иницијална лезија. Иако овие пациенти не беа третирани со локален флуориден третман, имаше значајно подобрувањето на ОНІиндексот кое се должеше на:одржувањето домашна орална хигиена според нашите инструк- ции, со правилно четкање на забите, правилна исхрана на детето, отстранување на шишето со цуцла (кај некои од испитаниците) исполнето со засладени содржини и редуцирање на чести меѓуоброци богати со шеќери.

На графикон 6р. 3 на сличен начин дадена е споредбата на третираните испитаници со иницијална лезија и суперфицијалналезијасо локалниот флуориден третман на крај од испитувањето, соиста статистички значајна разлика во однос на ОНІиндексот (Mann- 
Whitney U Test: $\mathrm{Z}=2,803 ; \quad \mathrm{p}=$ 0,0050). ОНІиндексот беше значајно подобар - понизок кај испитаниците со иницијална лезија, односно со ОНІиндекс од 2,1-3 веќе немаше ниеден испитаник.
Ова се должеше на реминерализирачкото дејство на флуоридите на иницијалните, почетни лезии и нивната улога во редуцирањето на меките наслаги од забните површини. ${ }^{12,13}$

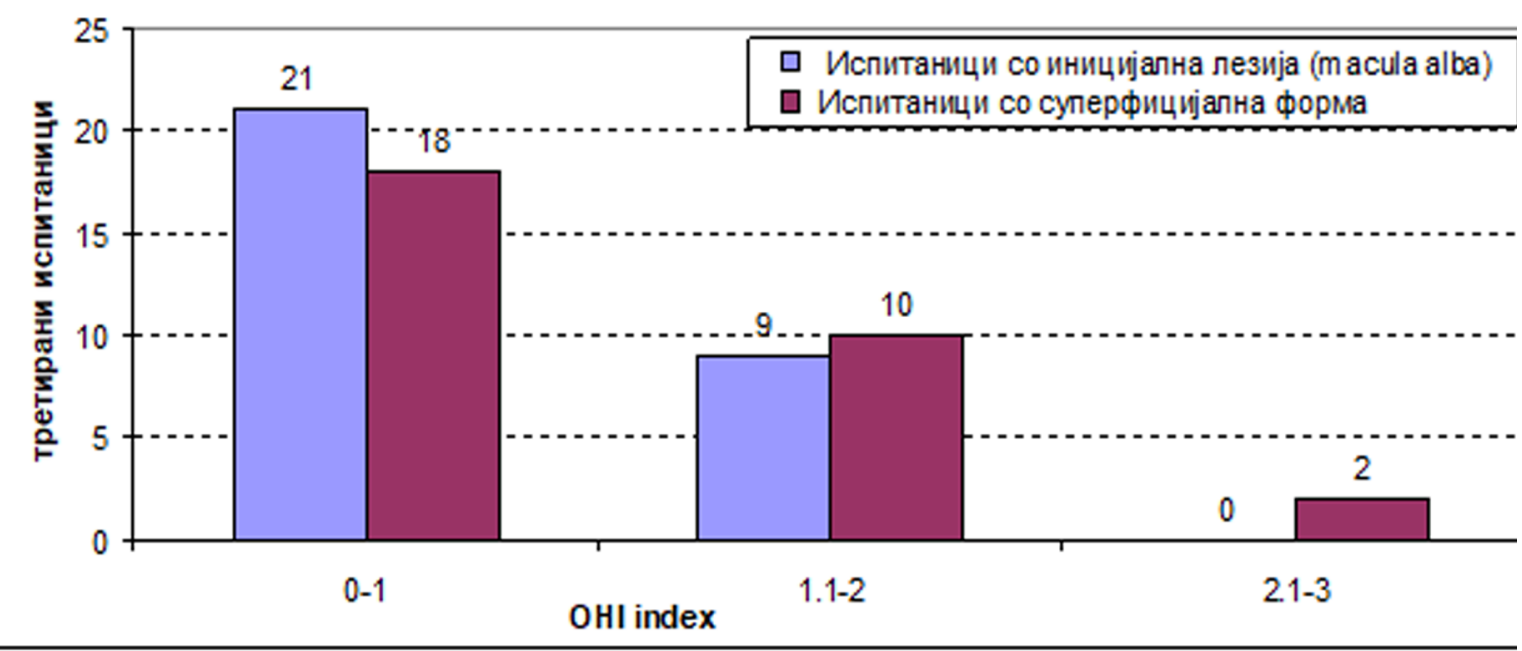

Графикон 3: Споредба на третираните испитаници со иницијална лезија и со суперфицијална форма на кариес

\section{Дискусија}

Значителното статистички сигнификантно подобрување на ОНІиндексот на оралната хигиена на крајот од ова наше петгодишно клиничко испитување, кај двете групи испитаници со иницијална и суперфицијална лезија третирани со локален флуориден третман, ни ги покажа кај нашите испитаници in vivo бенифитите кои ги имаме од флуоридните третмани и се докажани во многу други студии, пред сѐ во процесот на реминерализација на емајлот (глеѓта) кај иницијалната лезија ${ }^{21,22}$. Флуоридите исто така влијааат и врз редукцијата на меките наслаги и подобрување на индексот на оралната хигиена, ОНІиндексот за меки наслаги, кое е од особено значење кај нас во детската стоматологија. Во процесот на реминерализација на иницијалната, почетна лезија, флуоридите ја редуцираат продукцијата на киселини ${ }^{23,24}$ во оралниот медиум, а со тоа и го спречуваат критичниот пад на $\mathrm{pH}$ на плунката од 5,5 до 5, со што всушност се спречува појавата на кариес.

Затоа се поставува прашањето кога е најдобро и најефективно стоматологот да почне со локалниот флуориден третман. Земајќи го предвид фактот дека емајловата површина на новоеруптираниот емајл сѐ уште не е комплетно минерализирана ${ }^{8}$, а забите се најосетливи на кариогените нокси во првите неколку месеци од ерупцијата, локалниот третман треба да отпочне од двегодишна возраст, кога повеќето од млечните заби кај детето се веќе изникнати. ${ }^{1,5,7}$ 
Во фазата на иницијална лезија (macula alba) ${ }^{23}$ со отстранувањето на кариес причинителот (денталниот плак) од една страна, и преземање максимални превентивни мерки од друга страна: соодветен начин на исхрана на малото дете, саливација со нормален $\mathrm{pH}$ и состав на плунката, адекватна механичка и хемиска контрола на денталниот плак, со одржување на правилна орална хигиена и примена на локална апликација на флуоридни препарати во различни форми, се создаваат услови за преовладување на реминерализационите процеси во однос на деминерализационите, односно преовладување на протективните над патогените услови, со што се надоместува инсуфициентноста на минералите иможе да дојде до комплетно исчезнување и конвентирање, односно репарирање на иницијалната лезија,белата дамка во здрава глеѓ (restutio ad integrum). ${ }^{10,12,13,21}$

Во 2014 година, Oliveira и сор.24 спровеле клиничко испитување со локални апликации на флуориден варниш гел кај испитаници со иницијални лезии кај кариес на рано детство, во период од 24 месеци. И со овој флуориден препарат, кој е со слични својсва и ефекти на нашиот употребуван флуориден препарат, колегите исто така добиле реминерализација на иницијалните лезии и стопирање, т.е редукција на кариесот и подобрување на ОНІиндексот. Но, добиените резултати се со помала значајна статистичка сигнификантност во споредба со нашите. Ова се должи, пред сѐ, на помалиот број испитаници со иницијални лезии кои ги дијагности- цирале и вклучиле во третманот (испитаници на 5-годишна претшколска возраст, кога и дијагностицирањето на овие лезии е многу ретко). Иницијалните лезии, како што напоменавме и претходно, се јавувааат кај многу помали деца, веднаш по ерупцијата на млечните заби (меѓу 2 и 3 години), како што ги дијагностициравме и селектиравме кај нашите испитаници и ги вклучивме во испитувањето. За изведување на едно вакво испитување со многу мали испитаници, мора да се напомене дека педодонтот треба да е поткован со добро претходно искуство и стручност, за да му посвети многу трпеливост, внимание и време на детето, кое ќе му возврати со успешна взаемна соработка и задоволство.

Други средства кои може да ги споменеме, а се користат за локална флуоризација се средствата на база на $\mathrm{NaF}^{25}$. Истите може да се во вид на пасти за заби, гел, водички за испирање, лак и сл. 26 Можеме да споменеме и други флуоридни средства кои денес се актуелни на пазарот и се употребуваат во денталната медицина. Нанохидроксиапатит ${ }^{27}$ кој се додава во пастата за заби и средствата за плакнења на уста, прилагоден за реминерализација и спречување на кариес на забите, потоа 38\% сребро диамин флуоридкој се потврдилодека стопира повеќе иницијални кариозни лезии со намалена појава на кариес отколку користењето на $\mathrm{NaF}$ лак. Најновото достигнување од средствата за реминерализација е Curolox Technology, која се базира на присуство на самоврзувачки пептиди ${ }^{28}$. 
Знаејќи го предвид значењето на неинвазиваната стоматологија кај пациентите, деца помали од 18 месеци, неинвазивен третман за реминерализација на иницијална кариозна лезија денес е еден од елементите на кариес ризик менаџментот во Интернационална кариес класификација и менаџмент систем (International Caries Classification and Management System (ICCMS ${ }^{\mathrm{Tm}}$ )Водич за кариес менаџмент наменет за стоматолози и едукатори, чија цел е да се одржи здравјето со сочувување на структурата на забот и реставрирање само кога тоа е индицирано. ${ }^{29,30}$

\section{Заклучок}

Од спроведените анализи на добиените резултати, можеме да констатираме дека нивото на оралната хигиена е во корелација со прогресијата на промените во емајлот, односно пациентите со повисок ОНІиндекс најчесто се во групата на суперфицијален кариес. Оралната хигиена и флуоридниот третман значително влијаат врз намалување на нивото на меките наслаги и кај третираната група испитаници топикалниот флуориден третман има позитивен ефект врз индексот на оралната хигиена.

\section{Референци}

1. American Academy of Pediatric Dentistry Policy on Early Childhood Caries (ECC): classifications, consequences, and preventive strategies. Referencemanual. Pediatr Dent 2015;37(6):50-52
2. De Grauwe A, Aps JK, Martens LC. Early childhood caries (ECC): what's in a name? Eur J Paediatr Dent 2004; 5 (2):62-70.

3. Kokoceva-Ivanovska O, Georgiev Z, Sarakinova O, Shevale A, Todorovska G, Mijovska A, Natasha S. Early Childhood Caries. Physioacta 2017; 3(11): 51-56

4. Markova N. Early Childhood Caries. Sofia.2003;63(1):42-50

5. Тодоровска Г, Симјановска Љ, Тодоровска К, Кокочева -Ивановска О, Жабокова- Билбилова Е. Значењето на оралното здравје во периодот на млечна дентиција. Vox medici 2017; 25(96):495-500

6. Ambarkova V, Todorovska G, Kokocheva-Ivanovska O, Simjanovska Lj. The importance of sugar as predisposing factor for tooth decay. International Journal of Dentistry Research 2018; 3(1):1-4.

7. Kokoceva-Ivanovska Olga. The appearance of the "Baby bottle caries. Macedonian pharmaceutical bulletin 2017;64 (2): 19 - 22.

8. Leong PM1, Gussy MG, Barrow SY, de Silva-Sanigorski A, Waters E. A systematic review of risk factors during the first year of life for early childhood caries.. Int J Paediatr Dent 2013;23(4):235-50

9. Fontana M. The clinical, environmental, and behavioral factors that foster early childhood caries: evidence for caries risk assessment. Pediatr Dent 2015;37(3):217-25

10. Roopa KB, Pathak S, Poornima P, Neena IE. White spot lesions: A literature review. J Pediatr Dent 2015;3:

11. Veerkamp JSJ, Weerheijm KL. Nursing bottle caries: The importance of 
a development perspective. J Dent Child 1995; 62(6): 381

12. Kokoceva-Ivanovska O. Early childhood caries: Following of the early developing stages and possibilities for its prevention. Ph.D. Thesis. Faculty of Dental Medicine, University Cyril \& Methodius, Skopje, Macedonia. 2011:137-159

13. Kokoceva - Ivanovska O, Mijoska A, Gligorova D. EDS - Quantitative Microanalysis of calcium and phosphate in the initial lesion of a circular caries before and after the topical fluoride treatment. Research Journal of Pharmaceutical, Biological and Chemical Sciences 2016; 7(3): 2403-2406

14. Douglass JM, Douglass AB, Silk HJ. A practical guide to infant oral health. Am Fam Physician 2004;70(11):2113-20

15. Царчев М. Превентивна стоматологија. Скопје, 2006

16. Vulovic M. Beloica D, Gajic M, Stefanovic R. Preventivna stomatologija, Beograd: 2002

17. Rosin-Grget K, Lincir1 I, Tudja M. Effect of amine fluoride on enamel surface morphology. Coll Antropol 2000; 2: 501-508.

18. Chaffee BW, Feldens CA, Rodrigues $\mathrm{PH}$, Vitolo MR. Feeding practices in infancy associated with caries incidence in early childhood. Community Dent Oral Epidemiol 2015;43:338-48

19. Douglass JM, Douglass AB, Silk HJ. A practical guide to infant oral health. Am Fam Physician 2004;70(11):2113-20.

20. Todorovska K, Kokoceva-Ivanovska O, Markovska Arsovska M. Prevention in pediatric dentistry-health and bright smile. Physioacta 2016; 10 (1): 105-111.
21. Cury A, Andaló Tenuta LM. Enamel remineralization: controlling the caries disease or treating early caries lesions?. Braz Oral Res 23(Spec Iss 1) 2009:23-30

22. Amaechi BT, van Loveren C. Fluorides and non-fluoride remineralization systems. In: van Loveren $\mathrm{C}$, editor. Toothpastes. Monogr oral Sci. Basel: Karger; 2013;15-26

23. Olga Kokoceva-Ivanovska.The beginning phases of the early childhood caries (circular caries) - clinical evaluation of remineralization. Macedonian pharmaceutical bulletin, 2020; 66(2)

24. Oliveira BH, Salazar M, Carvalho DM, Falcao A, Campos K, Nadanovsky P. Biannual fluoride varnish applications and caries incidence in preschoolers: a 24-month follow-up randomized placebo-controlled clinical trial. Caries Res 2014;48(3):228-36

25. Amaechi BT, Ramalingam K, Mensinksai PK, Narjibfard K, Mackey AC, KarlinseyRL. Remineralization of eroded enamel by a NaF rinse containing a novel calcium phosphate agent in an in situ model: a pilot study. Clin Cosmet Investig Dent 2010;2:93-100

26. Garcia R, Borrelli B, Dhar V, Douglass J, Gomez FR, Hieftje K, et al. Progress in early childhood caries and opportunities in research, policy, and clinical management. Pediatr Dent 2015;37(3):294-9

27. Najibfard K, Ramalingam K, Chedjieu I, Amaechi BT. Remineralization of early caries by nano-hydroxyapatite dentifrice. J Clin Dent 2011;22(05):139-43 
28. Cochrane NJ, Saranathan S, Cai F, Cross KJ, Reynolds EC. Enamel subsurface lesion remineralisation with casein phosphopeptide stabilised solutions of calcium, phosphate and fluoride. Caries Res 2008;42:88-97.

29. Kobašlija S, Vulićević Z, Jurić H, i sar. Minimalna invazivna terapija. Sarajevo: Dobra knjiga; 2012.

30. International Caries Classification and Management System (ICCMS ${ }^{\mathrm{TM}}$ ) Guide for Practitioners and Educators. www.kcl.ac.uk/sspp/kpi/ projects/healthpolicy/global-cariesmanagement. 